\title{
A Economia Solidária e o Projeto de Outra Mundialização*
}

\author{
Luiz Inácio Gaiger
}

$\mathrm{N}$

estes últimos anos, a economia solidária revelou-se pródiga em encontros - de ativistas e de organizações dos diversos quadrantes do globo - em que se formularam proposições visando abrir caminhos para o avanço da solidariedade, como princípio ético-político e como esteio concreto de uma nova mundialização. $\mathrm{O}$ apoio unânime a essa desejada confluência se expressou particularmente nas edições do Fórum Social Mundial, em Porto Alegre. No contexto de uma nova consciência mundial quanto aos efeitos deletérios do capitalismo e ao fracasso das soluções de corte neoliberal, em brindar progresso material e liberdade aos povos, a economia solidária é projetada em cena como peça de resistência e como ensaio de outro projeto de sociedade, de uma globalização alternativa calcada na democratização da economia e na cidadania ${ }^{1}$.

A economia solidária é considerada um passo concreto, indispensável para dar credibilidade e gerar intensa adesão social aos propósitos de uma nova arquitetura mundial, prova necessária para evitar

\footnotetext{
* Este artigo tem como base estudos realizados no âmbito do Grupo de Pesquisa em Economia Solidária, da Universidade do Vale do Rio dos Sinos - UnISINOs (www.ecosol.org.br), com apoio do Conselho Nacional de Desenvolvimento Científico e Tecnológico - CNPq e da Fundação de Amparo à Pesquisa do Estado do Rio Grande do Sul FAPERGS.
}

DADOS - Revista de Ciências Sociais, Rio de Janeiro, Vol. 47, nº 4, 2004, pp. 799 a 834. 
apenas o oferecimento de uma ideologia mistificadora, de alternativas inaplicáveis. A despeito dos problemas conceituais e dos limites da economia solidária, adiante analisados, outra mundialização implica com efeito mundializar outras coisas: nada será insistentemente reivindicado no plano dos grandes atores, das políticas e dos arranjos institucionais responsáveis pelo desenvolvimento regional, nacional e mundial (que não esteja realisticamente experimentado e incorporado no plano micro, nas práticas de trabalho, de produção econômica e de participação cidadã). Caberia acrescentar, além do mais, como lembram Santos e Rodríguez, que no atual momento "Os critérios para avaliar o êxito ou fracasso das alternativas econômicas devem ser gradualistas e inclusivos" (2002:72).

No Brasil, é visível a expansão das iniciativas ditas de economia solidária. Por um lado, seus protagonistas diretos encontram-se pressionados pela crise estrutural do mercado de trabalho; por outro, vêem-se motivados pela ação mobilizadora de movimentos sociais, de parcelas do sindicalismo e de inúmeras entidades civis; pela oferta e impulsão desses agentes mediadores na direção de soluções coletivas. Ao mesmo tempo, estímulos adicionais decorrem do importante efeito demonstrativo das experiências já existentes, em particular naqueles segmentos populares dotados de substrato comunitário ou de identidade formada no trabalho (Gaiger, 2004). A conjuntura nacional instaurada em 2003, nas esferas de governo e nas articulações da sociedade civil, situa a economia solidária diante de novos horizontes, nos quais se apresentam novas escolhas e novas formas de atuação.

Ora, as experiências concretas de economia solidária, bem como os principais métodos de intervenção de agentes e organizações, geralmente padecem do seguinte dilema: como ir além de êxitos isolados e de ações focalizadas, produzindo efeitos de integração vertical e horizontal sobre as unidades econômicas e dando-lhes feições de uma real alternativa para a economia dos setores populares e dos trabalhadores em geral? O desafio maior parece ser romper fronteiras - sociais, geográficas -, superar limites - mentais, políticos, institucionais - e favorecer convergências inclusivas, de integração sistêmica da economia solidária, de modo a convertê-la em base social e econômica tangível de outro modelo de desenvolvimento. Do contrário, a multiplicação de iniciativas concretas pode deparar-se em pouco tempo com a ausência de ambientes e de mecanismos de retroalimen- 
tação, com o risco de vir a refluir e de estabelecer-se um quadro crítico, com tendências à estagnação.

Esse tema foi objeto de trabalhos anteriores (Gaiger, 1999; 2001a) com matizes diferentes. Neste ínterim, a evolução dos fatos veio a estampar com mais nitidez esses impasses. Tornou-se mais visível que o problema não se resume a uma insuficiência de meios, para que os modelos de intervenção e as políticas públicas ganhem outra escala, mas envolve as concepções que orientam tais práticas e os dispositivos metodológicos empregados. Sem que se renovem profundamente alguns dos paradigmas políticos vigentes, transferidos em sua maioria de outras frentes de militância e ação institucional para a economia solidária, esta se verá fadada a funcionar como mais um campo de disputas, entre frações e organizações mediadoras, e não de autêntico e inovador protagonismo social.

Para analisarmos com propriedade esses problemas, tomaremos o quadro de realizações da economia solidária no Rio Grande do Sul como principal referência, por apresentar um interesse particular: de um lado, ele posiciona-se na dianteira em algumas frentes, apoiado em sua tradição associativa e cooperativa e na sua história política recente, cujo centro hegemônico oscilou progressivamente à esquerda, ao encontro dos movimentos e organizações sociais; de outro lado, tais realizações refletem alguns dos dilemas cruciais para que o solidarismo se converta em um novo sistema de práticas, dotado de institucionalidade própria, e venha a superar seus atuais limites, no sentido de uma nova integração regional e mundial².

A gestão petista do Estado do Rio Grande do Sul (1999-2002), de par com a nova conjuntura nacional, induziria a que a reflexão sobre o tema se ativesse enganosamente a circunstâncias e fatos recentes, nos quais importantes perspectivas políticas e institucionais se abriram para o estado e para as organizações da economia solidária. Todavia, um pequeno recuo na história, tomando distância das questões então candentes no debate, deixará salientes raízes mais profundas do problema. A começar, que economia solidária é a denominação hoje aceita para designar uma realidade compósita, que abrange realidades sociais que evoluíram por razões e caminhos em geral independentes. Existem vertentes históricas do solidarismo econômico à margem do circuito onde se opera essa nova conceitualização. A ausência de integração, que hoje se reivindica em grau sistêmico, em verdade é uma 
marca de origem dessas diferentes experiências. À medida que os diversos segmentos e agentes da economia solidária seguirem reiterando os seus particularismos, aquelas experiências ficarão cativas de divisões alheias ao seu conteúdo social e às suas necessidades de expressão política.

Como a economia solidária poderá alicerçar uma nova lógica de desenvolvimento e de integração mundial? Para fundamentar essa reflexão, o texto resume os principais traços da economia solidária no Brasil e no Rio Grande do Sul. Essa caracterização deixará particularmente perceptíveis alguns aspectos de interesse, diante da questão que nos guia; em particular, a coexistência de modelos de promoção da economia solidária, cujo teor determina um estilo de ação com virtudes e limitações próprias. Por outro lado, o solidarismo econômico popular decorre, em boa parte, das contradições e insuficiências oriundas do mercado e do Estado, sinalizando o desejo de um arranjo emancipador dessas duas entidades históricas, mediante a constituição de um espaço público não-estatal. Para que participe efetivamente de um novo projeto de mundialização, a economia solidária demanda ainda que se vençam suas circunscrições atuais, impostas por barreiras do pensamento e da prática política. Sua consolidação como experiência histórica requer, no entanto, que se reconheça e se valorize o papel insubstituível dos seus principais protagonistas.

\section{A FORMAÇÃO DA ECONOMIA SOLIDÁRIA}

No Brasil, um novo solidarismo popular expressa-se na prática e no ideário de um número crescente de empreendimentos econômicos, levados à frente por trabalhadores premidos pela falta de alternativas de subsistência ou movidos por suas convicções. Esses empreendimentos se organizam das mais diversas formas, em associações informais ou grupos comunitários de produção, cooperativas e pequenas empresas. A exemplo do que se observa em outros países, em sua rápida profusão no Brasil essas iniciativas vêm adquirindo visibilidade e densidade social. A adesão crescente dos trabalhadores a alternativas de trabalho e renda de caráter associativo e cooperativo, ao lado da multiplicação de organizações representativas e de apoio, configura gradativamente a economia solidária como um novo campo de práticas, que (Gaiger, 2001a; 2003b; 2004): 
a) assumem, em dose variável, um caráter coletivo no tocante à posse dos meios de produção, ao processo de trabalho e à gestão do empreendimento, minimizando a presença de relações assalariadas e provocando envolvimento com os problemas da comunidade e com as lutas pela cidadania;

b) tendem a criar ou reforçar inúmeras instâncias de mediação e representação, tais como uniões associativas, federações cooperativas, redes de intercâmbio e organizações de fomento. À medida que logram fazer da cooperação produtiva e da sua articulação alavancas que as sustentam e as qualificam na economia contemporânea, adquirem chances de constituir uma economia do trabalho voltada à "reprodução ampliada da vida" (Coraggio, 1997:36; 2001a:6), a que imprimem um sentido e uma possibilidade emancipatória;

c) por sua inserção social e comunitária, cumprem adicionalmente uma série de funções, em saúde, educação, defesa de minorias, preservação ambiental etc., todas de interesse comum. A economia solidária coteja-se com o setor privado na criação de postos de trabalho e, com o Estado, na oferta de serviços sociais. Tende a rejeitar a separação entre o social e o econômico, a reconciliar a eficiência com a cooperação no trabalho e a estabelecer os fundamentos de uma socioeconomia (Arruda, 1998); e

d) alinham-se ao fenômeno mais amplo da economia alternativa ${ }^{3}$, que abrange múltiplos segmentos sociais, agentes e instituições e se apresenta como um movimento de crítica global ao sistema econômico capitalista, de acentuada tendência a encetar iniciativas concretas, em vista do desenvolvimento humano integral, individual, social e ecológico (Camacho, 1996). Participar dessas experiências contribui para a formação de identidades culturais, para subjetivações auto-referenciadas. Confluindo de diferentes situações concretas, das quais emergem e nas quais assentam suas identidades particulares, essas iniciativas se reconhecem mutuamente em tais práticas e valores e no ideal de transcendência histórica que as impulsiona.

As linhas determinantes da economia popular solidária não estão definidas, pois se apresentam em meio a ambigüidades e contradições. O uso corrente do conceito recobre um conjunto de iniciativas com motivações, origens e naturezas distintas, que não comportam tendências espontaneamente confluentes, que redundariam, por uma 
força natural de aproximação, em uma nova totalidade social, a abraçar integralmente as diversas formas de vida dos trabalhadores. Cabe ainda recordar que os sujeitos de boa parte das experiências pertencem aos extratos populacionais mais depauperados, "deserdados do capital, do conhecimento e do poder" (Cruz, 2002:13). Empreendimentos solidários nas periferias urbanas deparam-se com infindáveis dificuldades, embora estejam mais próximos das forças dinâmicas da sociedade e da economia, ao lidarem com situações de alta instabilidade econômica, quando não de extremada pobreza, de desenraizamento social e cultural. Setores sociais expostos a esse nível de degradação, premidos pelas circunstâncias, vivem, em geral, em uma solidariedade compulsória, sem transformá-la em valor e norma interior de vida. As práticas associativas certamente contribuem para a introjeção racionalizada da solidariedade, uma vez que criam espaços para a sua prática intencional e cotidiana. No entanto, sob a noção de comunidade, por vezes mistificada no imaginário dos agentes, esconde-se uma trama de sociabilidades cambiantes e conflitivas, tornando frágil a base para a construção de experiências consistentes e duradouras.

Isto posto, o aporte mais valioso das experiências de economia solidária é propiciar uma nova práxis do trabalho, que freia a degradação do trabalhador e rompe o ciclo reiterativo da consciência, em uma época em que o regime de acumulação capitalista deixa as pessoas à deriva (Sennett, 1999) e impõe enorme esforço, teórico e prático, de resgate dos sentidos do trabalho (Antunes, 1999). Ao reconciliar o trabalhador com o processo e os frutos do seu labor, oferece-se a possibilidade de superar o caráter descartável e alienante da atividade produtiva, de elevá-la a um patamar de satisfação de aspirações não apenas materiais ou monetárias. $\mathrm{O}$ trabalho fundado na solidariedade restitui as condições de reflexividade, impele à subjetivação, em cuja experiência (Dubet, 1994) estampa um conteúdo intrinsecamente axiológico e projetivo. No lugar de supor a presença de um "homem novo", tal como Nove (1989) aponta corretamente ter ficado subentendido na teoria econômica do socialismo, abre uma via real para sua constituição.

Ao mesmo tempo, a economia solidária está demonstrando que a cooperação e a autogestão não são meros ordenamentos éticos, pois encerram vantagens no comparativo com as formas ordinárias de economia. Em determinadas circunstâncias, empreendimentos associa- 
tivos logram consolidar-se e alcançar níveis de acumulação que os habilitam a um processo de crescimento endógeno (Peixoto, 2000; Singer e Souza, 2000; Santos, 2002). Assumindo uma racionalidade econômica própria e planificando seus investimentos, compatibilizam e reforçam a cooperação no trabalho e a rentabilidade econômica. O primeiro elemento é a chave mestra a tornar essas iniciativas superiores ao trabalho artesanal e individualizado dos produtores autônomos, bem como mais produtivos do que empresas convencionais análogas ${ }^{4}$.

O potencial emancipatório dessas alternativas de produção e as suas perspectivas de êxito "dependem, em boa medida, da integração que consigam entre processos de transformação econômica e processos culturais, sociais e políticos" (Santos e Rodríguez, 2002:64). Para que se possa traçar o caminho a ser trilhado nessa direção, é necessário ter em conta que a economia solidária nasceu e flui por diferentes veios, $\mathrm{o}$ que nos leva a um exame mais acurado de sua formação. Pelas razões antes apontadas, ilustraremos a questão com o caso do Rio Grande do Sul.

Comparativamente ao resto do país, este estado possui considerável tradição associativa e cooperativa, cujas raízes mais longínquas repousam na forma de ocupação do território, no século XIX, por agricultores imigrantes da Europa, que se estabeleceram nas novas terras em regime de produção familiar, ao redor de pequenas comunidades rurais. Essa vertente rural mais antiga do associativismo se expressa hoje por um sem-número de associações de apoio à pequena produção agrícola, disseminadas em quase todo o estado, organizando coletivamente a produção ou o trabalho. Tais associações ficaram sem se articular em um movimento específico e deveras condicionadas aos programas assistenciais do estado. Muito embora restritas em seus fins e espaços de atuação, além de desprovidas de instâncias de expressão e representação, elas têm preservado a cultura associativa no meio rural, dando lastro a muitas cooperativas de pequenos agricultores.

As cooperativas, por sua vez, experimentaram um crescimento constante nas décadas de 40 a 70, inicialmente sob o impulso de lideranças católicas junto a agricultores familiares; a seguir, assumiram feições empresariais, em razão do predomínio político dos médios e grandes produtores rurais. As empresas hoje filiadas ao sistema cooperativis- 
ta oficial constituem o setor mais numeroso no estado, com predominância das cooperativas agropecuárias, modelo básico até os anos 80 . Nesse contexto, as cooperativas findaram resumindo-se a uma modalidade de empresa econômica, visando reforçar o poder de classe dos produtores rurais e garantir melhor barganha dos recursos públicos, do que decorreu sua forte dependência das políticas de governo direcionadas ao setor e da capacidade de suas lideranças em transacionar com as forças políticas instadas ao poder.

A expansão das cooperativas permaneceu considerável nos últimos anos, com taxas superiores à média nacional. São, contudo, as cooperativas de trabalho que tomaram a dianteira, atraindo contingentes urbanos egressos do mercado ou da economia informal. Por conta do seu papel formador do cooperativismo riograndense e da sua diversidade atual, esse setor se apresenta em nossos dias extremamente heterogêneo, sendo controverso o quanto encerra de empreendimentos com autênticas qualidades de solidarismo. As cooperativas de trabalho, em que os sócios vivem da ocupação por elas garantida, introduzem um novo personagem e reconfiguram o setor, abrindo um flanco de comunicação com a realidade operária e o movimento sindical. Do ponto de vista da condução política recente do cooperativismo, é visível um movimento de aproximação à nova linguagem da economia solidária e das suas redes e organizações (Sarria, 2002).

A mudança do quadro acentuou-se no final dos anos 80, com o florescimento e a revitalização de experiências associativas de autogestão, de clara extração popular. No Rio Grande do Sul, elas foram impulsionadas à raiz da emergência e atuação de movimentos sociais e, principalmente, de diferentes organizações de apoio aos trabalhadores, dando lugar a segmentos ${ }^{5}$ com uma fisionomia singular, explicativa de suas respectivas trajetórias e de suas possibilidades de evolução. Sem negar o caráter autenticamente popular de muitas iniciativas, a formação da economia popular solidária decorreu em grande medida dessas mediações externas e, por conseguinte, da sua influência às vezes decisiva. Por essa razão, a descrição desses setores e linhas de atuação é o melhor caminho para apreender o perfil e as tendências da economia popular solidária na região .

No campo das experiências comunitárias, a frente mais antiga de trabalho data dos anos 80 e deve-se à Cáritas Brasileira, que atua nas diferentes regiões do estado, tendo apoiado mais de mil pequenos em- 
preendimentos, dos mais diversos setores de atividade, através de crédito, suporte técnico e de uma metodologia destinada a formar a consciência crítica, socialmente engajada. Além de atenuar a falta de oportunidades de trabalho, o programa objetiva propiciar a experimentação de novas práticas econômicas, servindo, então, como base para a implementação de alternativas mais abrangentes. Os projetos devem ter finalidade prática - de produção econômica ou prestação de serviços - e cunho educativo que desenvolva o espírito comunitário e a consciência, de modo a gerar um novo modelo nas relações entre capital e trabalho (Cáritas Brasileira, 2003); com o alargamento progressivo dos seus horizontes de ação, seriam ao mesmo tempo sinais e forças atuantes na transformação da sociedade.

Ao longo do seu trabalho, a Cáritas gerou conceitos e instrumentos metodológicos de largo trânsito no campo da economia solidária e inspirou ações similares de outras organizações, especialmente as vinculadas ao ambiente pastoral. A linguagem que utiliza se encontra altamente difundida entre as demais agências. Cunhou também uma metodologia de acompanhamento dos grupos populares, adaptada a ações de longo prazo e tendo o apoio creditício como instrumento, entre outros, para uma ação educativa e promocional que se desdobra em várias frentes, pedagogicamente indissociadas. Exerceu, ainda, um papel de vanguarda na transição de um modelo voltado apenas ao atendimento de demandas momentâneas para um modelo de promoção e sustentação continuada das experiências econômicas.

Em faixa própria, o Movimento dos Trabalhadores Rurais sem Terra MST, de longa atuação no Rio Grande do Sul, há duas décadas promove a criação de sistemas coletivos de produção nos assentamentos rurais, vinculados à Cooperativa Central dos Assentamentos do Estado. Sobre o processo controverso de organização dos assentamentos, há registro de resultados estimulantes, nos planos socioeconômico e educativo, embora persistam graves dificuldades em razão das carências materiais, do despreparo técnico e de visões coletivistas, bancadas pela direção do MST, às vezes pouco condizentes com a cultura de classe dos agricultores. De todo modo, tais práticas de coletivização, sob a condição de se mostrarem flexíveis à realidade de cada família e cada comunidade, apontam um caminho adequado para a prosperidade dos agricultores assentados e dos pequenos produtores em geral ${ }^{7}$. 
Tais são as principais vertentes e organizações sociais da economia solidária, em que se busca forjar uma identidade social e uma unidade discursiva em torno de valores como trabalho, cooperação e autogestão. Ao mesmo tempo, à medida que se expande e diversifica, adquirindo um poder de impacto exponencialmente maior, o novo solidarismo confronta-se com maior pluralidade de concepções, objetivos e métodos de trabalho ${ }^{8}$. Nas diversas realidades regionais do país, a multiplicação de protagonistas e de iniciativas é um fato comum. Somando-se às entidades há mais tempo vocacionadas para esse campo de atuação, aparecem novas Organizações Não-Governamentais - ONGs, movimentos sociais emergentes e instituições até há pouco alheias a esse campo, como as universidades e as fundações empresariais. A convergência de propósitos e as interações entre esses agentes vêm predispondo ao fortalecimento de consórcios e práticas de colaboração, formando com isso, gradativamente, uma cultura de parceria. Estruturam-se redes de formação, federações cooperativas, sistemas de troca e uniões diversas entre os empreendimentos cuja maior expressão é o Fórum Brasileiro de Economia Solidária instaurado em 2003. No imaginário anticapitalista que os move, cultiva-se a idéia de que a construção de alternativas exige ultrapassar as fronteiras nacionais (outrora baluarte das lutas de resistência contra as pressões imperialistas), na mesma direção sobejamente apontada pelos movimentos antiglobalização e pelas teses dominantes nas edições do Fórum Social Mundial.

Por outro lado, a sorte da economia solidária depende de um novo sistema de regulação, capaz de ordenar dinamicamente as regras do jogo econômico, de modo a expandir as práticas de autogestão e viabilizar uma transposição de escala das iniciativas que proliferam em pequena dimensão. Uma questão política, portanto, de escolha entre modelos de desenvolvimento, de chamada e fortalecimento de novos atores sociais e de direcionamento dos recursos públicos. Seu avanço requer que a questão seja assimilada pelas instituições políticas e se reflita na conduta do Estado e nas opções de governo. De modo crescente, o fato vem se verificando no Brasil, especialmente no âmbito local, por meio de políticas municipais. Nos últimos embates eleitorais, ele esteve presente, se não explicitamente nas formulações programáticas das coalizões partidárias, ao menos nas preocupações das lideranças mais organicamente expressivas das demandas dos movimen- 
tos sociais. A criação da Secretaria Nacional de Economia Solidária, em 2003, é a sua manifestação mais concreta.

\section{Desencontros e Debilidades Sistêmicas}

A levar-se seriamente o desafio da articulação orgânica, outras entidades e linhas de atuação devem ser ainda contabilizadas, pois, embora não incidam diretamente sobre os empreendimentos da economia solidária, respondem a necessidades da mesma população e possuem fins semelhantes, vincados na promoção da solidariedade. Ao tomar-se novamente o caso do Rio Grande do Sul, para adentrarmos esse universo, veremos que ali se encontram ações nacionalmente referenciais em suas respectivas áreas de atuação, ou representativas do que se observa no país. Fato mais relevante, examinado adiante, a atuação dessas diversas organizações sugere que a passagem das $e x$ periências de apoio à economia solidária, adotadas em cada segmento, para políticas de largo alcance, não poderá derivar simplesmente da universalização de um único modelo, mas, sim, da arte de conjugar diferentes possibilidades de resposta para demandas variadas de direitos e cidadania, distintas e igualmente legítimas.

Assim, coube ao Centro de Apoio aos Pequenos Empreendimentos - CEAPE Ana Terra ser pioneiro no apoio solidário a pequenos empreendedores individuais, ao introduzir práticas de confiança mútua na intermediação do crédito e na formação gerencial. Seu serviço é visto como uma forma de combate à pobreza, pela criação e fortalecimento de postos de trabalho em estratos de baixa renda e, igualmente, por seus efeitos indiretos, como a diminuição da evasão escolar, a valorização da mulher e a promoção da cidadania. Sua clientela majoritária compõe-se de empreendedores familiares, alijados do sistema financeiro convencional por causa da precariedade dos seus negócios e da falta de garantias reais. Uma modalidade de empréstimo, introduzida no Brasil pelo CEAPE, é a Fiança Solidária: pessoas com pequenos negócios associam-se em confiança e avalizam mutuamente os créditos contraídos. O processo seleciona naturalmente os bons pagadores e incrementa os laços pessoais e as práticas de mútua ajuda. A oferta de créditos sucessivos tem por fim adicionar um poderoso estímulo ao negócio e agregar um caráter educativo ao aporte financeiro. Desde 1987, o CEAPE viabiliza suas ações por meio de parcerias com instituições públicas, fundações benemerentes e com diversas associações de pequenos e microempresários, além de buscar recursos em bancos es- 
tatais de fomento. Foi quem iniciou as operações de microcrédito no país, como primeiro elo de uma cadeia nacional de Centros, inspiradora de inúmeras organizações similares.

Outra iniciativa de referência na área creditícia é a Instituição Comunitária de Crédito Porto Alegre Solidariedade - Portosol, inaugurada em 1996. A Portosol atende donos de pequenos negócios dos municípios da região metropolitana, como feirantes, costureiras, taxistas, comerciantes e artesãos. Além dos avais convencionalmente praticados, aceita como garantia a formação de grupos solidários, cujos membros contraem financiamentos de igual valor e se responsabilizam mutuamente pelos débitos individuais. A marca distintiva do banco, a exemplo de experiências internacionalmente consagradas, é a relação com a clientela, personalizada no agente comunitário de crédito. Ao banco incumbe aproximar-se do cliente, avaliar a solvabilidade do seu negócio, calcular suas condições de pagamento e monitorar as atividades financiadas, instituindo um relacionamento com base no conhecimento pessoal e na transparência. Trunfo decisivo é a aceitação de distintas modalidades de garantia para os empréstimos contraídos: fiador ou avalista, reserva de domínio das aquisições ou bens alienáveis, "avais solidários" e fórmulas mistas. São premissas do trabalho valorizar a autonomia e a iniciativa própria dos beneficiários, operar com eficiência e estabelecer vínculos duradouros com a clientela. Esse método de avaliação do crédito e de relacionamento com o cliente é um patrimônio importante, graças ao qual a Portosol se tornou uma concorrida repassadora de tecnologia para outras instituições ${ }^{9}$.

Nos últimos anos, o surgimento constante de novas iniciativas e a expansão da demanda às entidades e órgãos públicos denotam um panorama geral de ampliação do contingente atraído pelas propostas associativas. As organizações perfiladas explicitamente pela causa da economia popular solidária contestam a lógica dominante do capital, em particular as chamadas estratégias neoliberais, da mesma forma como rejeitam o conservadorismo social e político do cooperativismo oficial. Entretanto, o raio de alcance dos principais programas de fomento, a penetração social dos diferentes segmentos da economia solidária e o próprio desempenho econômico dos empreendimentos são modestos. Desse ponto de vista, eles ficariam seguidamente desprovidos de qualquer impacto social apreciável, não fora a enorme fragilidade que caracteriza a absoluta maioria das pequenas 
empresas, diante das quais os empreendimentos solidários apresentam vantagens às vezes de decisiva importância ${ }^{10}$.

Assim, a despeito daqueles limites e por conta de um contexto econômico globalmente adverso, o aspecto mais digno de interesse da economia solidária, no estágio atual, provavelmente é a capacidade de resistência dos empreendimentos, em particular quando indissociável da consolidação do seu caráter cooperativo e autogestionário. Nesses casos, democracia, participação e produtividade entram em simbiose, em contraponto à racionalidade da empresa capitalista. Mesmo em proporções limitadas, geograficamente localizadas, tais empreendimentos garantem a inserção pelo trabalho, alimentam os mercados circundantes, formam lideranças e dinamizam os circuitos de mobilização social e política ${ }^{11}$.

Esse enraizamento local contrasta com o estado disperso e pouco articulado da maior parte dos empreendimentos. Tentativas de suprir essa lacuna se sucederam, porém sem o resultado esperado, não apenas por causa de seu caráter policêntrico, mas da ausência de forças com suficiente poder de aglutinação. Dadas suas prerrogativas institucionais e seu raio de ação, apenas o Estado parece deter a capacidade de ativar políticas abrangentes, provocar ampla mobilização social e viabilizar novas estruturas econômicas. Por isso, com a chegada do Partido dos Trabalhadores - PT ao poder, inicialmente na capital Porto Alegre (1988), dez anos depois ao governo do estado (1998), em resultado inédito de ampla e bem-sucedida sustentação das organizações e movimentos sociais, uma mudança de panorama passou logicamente a ser esperada.

Além da criação da Instituição de Crédito Portosol, já referida, o poder público em Porto Alegre concentrou sua ação no fomento a grupos de baixa renda, visando a sua organização econômica associativa. As políticas do município direcionaram-se principalmente ao setor informal, compreendendo associações de reciclagem do lixo urbano, e a grupos de produção nos ramos de artesanato, confecções e prestação de serviços ${ }^{12}$. Além da formação gerencial e da intermediação de recursos, a Prefeitura de Porto Alegre oferece a determinados grupos um período de incubação, durante o qual instalações adequadas servem ao funcionamento e à consolidação de novos empreendimentos. Essa segunda linha de trabalho, todavia, ficou restrita a poucos empreendimentos e não logrou exercer um efeito demonstrativo convin- 
cente. A lentidão burocrática do aparelho estatal, somada à descontinuidade das políticas implementadas e, principalmente, ao modo diferenciado de concebê-las, pelas sucessivas administrações, resultou em baixo impacto sobre a economia popular do município, sem produzir a necessária dinamização sistêmica entre os diversos agentes produtivos nem gerar estruturas de escala, propícias ao seu efetivo desenvolvimento ${ }^{13}$.

A gestão do PT no governo do estado (1999-2002) teve como pedra angular a busca de um padrão endógeno de desenvolvimento, calcado na recuperação e revitalização da matriz produtiva do estado, de acordo com as potencialidades de cada uma de suas regiões. Como premissa, considerou o conjunto de forças produtivas, até então inaproveitadas, como suscetível de alavancar o crescimento econômico, desconcentrar a renda e diminuir a dependência tecnológica e financeira da economia gaúcha. A implementação de tais diretrizes provocou a suspensão de políticas anteriormente utilizadas, como a atração de grandes empresas por meio de incentivos fiscais e a privatização de instituições públicas, financeiras e de serviços. A opção pela dinamização das cadeias produtivas localizadas foi vista como instrumento distributivo da riqueza, pelo incremento decorrente no nível de emprego e na qualidade de vida da população. De outra parte, esses objetivos estariam a exigir do Estado maior capacidade de intervenção, seja no diagnóstico dos principais entraves ao desenvolvimento seja na indução estratégica dos diferentes segmentos sociais e setores produtivos.

O suporte às estruturas produtivas da economia solidária, junto com políticas de apoio a pequenas empresas e a empreendimentos de base familiar, figuraram entre essas estratégias. A fim de concretizá-lo, programa específico foi lançado para combater o desemprego, pela criação de trabalho em moldes não capitalistas, em que se desenvolviam práticas emancipatórias do trabalho (SEDAI, 2001). Nos seus dois anos de operação, o impacto do programa verificou-se em três aspectos:

a) pela primeira vez, no país, a economia solidária integrou a agenda de um governo estadual como estratégia de desenvolvimento e metas específicas. Além de haver propiciado a modelagem e a experimentação de políticas abrangentes, deu considerável visibilidade política e institucional ao tema, integrando-o à pauta de vários órgãos do apa- 
rato estatal e levando-o a disputar prioridades de investimentos no interior do governo e por meio dos instrumentos de consulta à sociedade;

b) a economia solidária difundiu-se em várias regiões do estado e em diferentes setores da sociedade, produzindo efeitos de atração e mobilização de administrações municipais, instituições de ensino, sindicatos, bem como a formação de agentes e de organizações locais, que se integraram ao campo. A atuação do estado e dessas organizações levou ao desenvolvimento de competências e instrumentos específicos, entre eles o diagnóstico técnico-produtivo, técnicas de gerenciamento da autogestão e o crédito assistido ${ }^{14}$;

c) apareceu um novo segmento da economia solidária na paisagem do Rio Grande do Sul: cooperativas da indústria de transformação oriundas da reconversão de fábricas capitalistas, nas quais se aplicou boa parte dos recursos e dos instrumentos de apoio agenciados pelo governo.

A efêmera execução do programa dificulta julgar sua eficácia e avaliar a solidez das empresas apoiadas. Do ponto de vista das insuficiências, no entanto, vale destacar:

a) as ações ficaram sistematicamente aquém das metas propostas, gerando resultados muito modestos para alterar os dados quantitativos do problema. Diante da demanda crescente, faltaram investimentos em montantes mais expressivos, maior preparo técnico e maior domínio dos fatores que intervêm na dinâmica dos empreendimentos e nas alternativas de superação. A eficiência dos projetos permaneceu altamente questionável;

b) desencontros na implementação política do programa e descontinuidades nas linhas de ação impediram-nas de cumprir-se organicamente e de somarem benefícios. Em detrimento do papel ativo das organizações representativas dos segmentos da economia solidária, o governo atraiu para si o comando das ações, segundo diretivas emanadas de pólos de poder em disputa no interior do aparelho de Estado. Decisões unilaterais, ou percebidas como estando vinculadas a grupos de interesse, passaram a provocar conflitos sucessivos entre os atores, minando expectativas e retirando do governo boa parte do crédito político com que iniciara o mandato. Paradoxalmente, no campo da economia solidária, o estado da participação popular mos- 
trou-se incapaz de galvanizar com eficácia as forças da sociedade e de conjugar frentes duradouras de ação em vista de um projeto comum $^{15}$.

A economia popular solidária no Rio Grande do Sul apresenta áreas com algum dinamismo, mas escassa integração sistêmica. Na agenda de consenso das ações para os próximos anos, um dos principais itens consiste em implantar programas de envergadura, de efetivo poder de impacto, local e regional. Ações, portanto, que venham a influenciar os índices de ocupação de mão-de-obra, de distribuição de renda e de qualidade de vida. $\mathrm{O}$ balanço do período recente indica ter havido um processo de experiências modelares, tanto de alternativas de organização dos empreendimentos quanto de mecanismos de sustentação. A tarefa reside, portanto, em fazer confluir as iniciativas em andamento, transferindo suas melhores soluções para uma estratégia dirigida a amplos contingentes da população, o que comporta várias exigências.

\section{Primeira exigência: relativizar e integrar os modelos de ação}

No Rio Grande do Sul e no país, de modo geral, os estilos de trabalho dos principais programas de economia solidária evoluíram basicamente por vias paralelas, sem uma articulação institucional orgânica a ensejar ações conjuntas e duradouras. À falta de uma ação eficaz do estado naquela direção, suas trajetórias produziram linguagens específicas e legaram lições que devem ainda ser socializadas para que a economia popular solidária se projete como expressão de um campo multicentrado e, mesmo assim, dotado de linhas propulsoras confluentes. Esse esforço exige relativizar os prismas interpretativos das entidades mediadoras, com suas respectivas premissas ideológicas, para construir uma racionalidade política determinada pelas necessidades e urgências que o desenvolvimento da economia solidária está a apresentar. Vale, a propósito, comparar, no Rio Grande do Sul, o método de ação daquelas organizações instituintes da economia solidária, intimamente relacionadas aos movimentos populares, com os programas voltados à mesma faixa da população, porém desprovidos de laços com tais movimentos e tampouco pressupondo a inserção do seu público-alvo em formas coletivas de mobilização.

No primeiro caso, situa-se o programa de Projetos Alternativos Comunitários, iniciado pela Cáritas em 1986. Por intermédio da rede de pa- 
róquias e comunidades católicas, a Cáritas fomentou centenas de projetos em zonas urbanas e rurais, principalmente nas periferias das cidades e em regiões de pequena produção agrícola, buscando converter os grupos beneficiários em sujeitos autônomos do seu próprio desenvolvimento social e econômico. Resta que esse trabalho atenda a setores sociais dos mais desguarnecidos, que esperam da Igreja um papel provedor diante da ineficácia das políticas sociais do Estado. Para suscitar formas de solidariedade duradouras e desejos de autonomia, a Cáritas vale-se do fato de que, nesses ambientes, o reconhecimento mútuo e a convergência de interesses apenas podem nutrir-se da convivência diária, dos laços de vizinhança e da partilha de culturas arraigadas. Em meio ao quadro degradante e anônimo da urbe, e com maior razão em meio rural, quando afeita a agricultores familiares depositários de uma tradição católica, a Cáritas encontra nos laços comunitários o terreno fértil para o desenvolvimento da solidariedade. Sua atuação ganha pleno sentido diante dos objetivos transcendentes que a orientam: formar consciências críticas, imbuídas dos valores cristãos e profundamente comprometidas com a transformação social. Um horizonte de projeto, de par com a metodologia de germinação de grupos e de engajamento e fusão em uma causa comum, formam os grandes vértices do programa da Cáritas.

Questões surgem ao imaginar-se a universalização do modelo, posto que ele parte de um substrato específico: a teia de laços comunitários, cevados entre as comunidades católicas de base, em que se estabelece um fusionamento constante dos grupos de ação. Nesse ambiente de contínuas interações, destila-se uma linguagem particular, presa a uma certa visão da realidade social, dotada de poderosos efeitos simbólicos e práticos. A despeito das intenções e da pedagogia includente empregada, a lógica objetiva dos fatos exige como necessário ser parte do povo em marcha para obter os qualificativos que tornam alguém reconhecido no trânsito intenso do solidarismo popular. Em outras palavras, o trabalho da Cáritas supõe a formação de uma identidade e de um ethos prévio dos seus beneficiários, forjados em um modo particular de inserção social, sem os quais esse modelo de trabalho tem as suas vias de acesso estreitadas.

A questão fica mais clara ao se examinar uma modalidade de atuação extremamente comum no país, exemplificada no Rio Grande do Sul pelo Fundo de Miniprojetos. Gerenciado por ONGs, objetiva dar suporte financeiro a movimentos populares e pastorais sociais, mediante 
repasse a grupos de produção, organizações de base, projetos de articulação de entidades e atividades pastorais. Demandas procedentes das mais diversas regiões do estado são avaliadas por um conselho formado por representantes das entidades gestoras, das pastorais populares e dos movimentos sociais. A seleção dos projetos leva em conta o caráter inovador das propostas, sua dimensão educativa, seu espírito democrático e solidário e seu efeito multiplicador. O Fundo é manejado como um instrumento a serviço de causas e objetivos maiores, como um apoio tópico a atividades que se entende estarem inseridas em um amplo e gradativo processo de transformação social. Sua repercussão material é pequena, sendo débil seu impacto sobre a teia pastoral dos movimentos. Não obstante, desperta interesse por suas características ilustrativas de uma fórmula de trabalho muito usual entre ONGs e agências internacionais, e por cristalizar alguns dos problemas apontados no trabalho da Cáritas, porquanto segue o mesmo modelo com matizes mais acentuadas; dadas as suas finalidades maiores, o fomento aos projetos ficaria desprovido de sentido sem a mística da luta por uma nova sociedade e seria, provavelmente, tido por inócuo.

O questionamento a fazer refere-se à endogenia contida nesse modelo de engajamento. Além dos critérios de seleção evocados, os grupos necessitam estar pré-qualificados, mediante recomendação de pessoas e entidades com circulação no ambiente da pastoral e dos movimentos. Por conseguinte, o público-alvo encontra-se previamente determinado, o que acarreta problemas caso se queira generalizar o modelo como serviço público para os empreendimentos solidários, quando então há chance certa de inexistirem aqueles pressupostos. O projeto político, ao embalar as ações movimentalistas (Doimo, 1995), termina por reduzir o raio de abrangência de programas dessa natureza e a descartar outros sujeitos, dado o jogo de legitimações que impõe. $\mathrm{O}$ movimento pastoral popular, como qualquer outro, representa uma parcela do universo social; não obstante sua linguagem encompassadora, está eivado de identidades internas sobrepostas a disputar entre si as representações legítimas e os recursos de poder nele produzidos.

A economia solidária é motivo e fruto da organização popular, mas não poderá seguir se expandindo apenas nesses setores organizados, sem instrumentos que a estendam aos trabalhadores deixados à margem dos mecanismos de representação coletiva de interesses. O campo solidário deve ser permeável ao trânsito dos sujeitos e tolerante à 
manutenção simultânea de diferentes vínculos, pois neles os trabalhadores encontram, por uma estratégia naturalmente oscilante, chances de sobrevivência material e sociocultural, lidando com identidades simultâneas. Vão em sentido oposto aqueles programas orientados com demasiada especificidade e alta condicionalidade (Coraggio, 2001a), sobretudo quando o peso entre o agente mediador e o beneficiário é desigual, facilitando para o primeiro eludir as intenções e as regras do jogo que efetivamente está a imprimir. Preferível à simulação de uma simetria inexistente, talvez seja simplesmente se abster de formar a consciência, e não pressupor redes de interação em que os indivíduos se devam colocar. Essa parece ser, justamente, a lógica das instituições alheias ao ambiente movimentalista.

O CEAPE Ana Terra, como vimos, atende uma clientela de baixa renda com a intenção de tornar viável seus empreendimentos e valorizar seu trabalho. Sua atuação caracteriza-se pela especialidade em conjugar o crédito e a formação, duas carências indiscutivelmente fundamentais dos pequenos empreendedores. No Rio Grande do Sul, essa linha de trabalho desempenhou um papel de vanguarda, tanto em seus propósitos gerais quanto na introdução de tecnologias específicas, como o atendimento personalizado adaptado às condições de cada cliente, e o financiamento de Grupos Solidários. Um dos resultados mais importantes tem sido demonstrar que o investimento em pequenos empreendedores é uma alternativa economicamente viável, além de ser um imperativo de qualquer proposta de desenvolvimento dotada de mínima racionalidade social ${ }^{16}$.

Uma objeção feita ao CEAPE diz respeito à visão empresarial que veicula e busca introduzir em sua clientela: os requisitos e técnicas de gestão dos negócios, embora observando preceitos éticos, estão desprovidos de qualquer conotação crítica quanto à lógica do mercado e aos imperativos da acumulação capitalista. Tenciona-se inserir novos atores econômicos no mercado, aparelhando-os com as mesmas armas dos demais concorrentes. Essa tônica no êxito do negócio esmaece outros componentes das relações sociais e do sentido da cidadania, ao descartar uma apreensão abrangente e integradora da vida e das práticas econômicas. Um segundo problema refere-se ao foco posto nos indivíduos potencialmente empreendedores, sem maior chance de se criar vínculos associativos duradouros e, mais amplamente, sem trazer ao primeiro plano os laços comunitários em que, eventualmente, estão envolvidos os seus clientes. O solidarismo, embora cul- 
tivado como um valor geral, fica subordinado aos fins individuais de cada empreendimento. Apenas pela força das circunstâncias, outras ações terminam sendo estimuladas com algum saldo em organização e mobilização coletiva.

O CEAPE afasta-se do modelo de engajamento. Seu compromisso consiste em atender às demandas que tecnicamente se enquadram em seu programa de ação, abstraindo qualquer outro traço do credo e da inserção social de seus clientes, que passam então a ser sujeitos de relações contratuais sucessivas. Como esse modelo de atuação, dada a história do CEAPE, se originou e cresceu mediante constante interlocução com a malha de entidades empresariais ${ }^{17}$, é tentador interpretá-lo como simples emanação de uma visão de classe, servindo ao seu desiderato de hegemonia. Entretanto, as ações da Portosol, agência idealizada por um partido de corte antiburguês, rompem esse esquema dual e deixam aflorar problemas de fundo, ao menos quando se entende a promoção do solidarismo como um vetor da cidadania.

A principal diretriz da Portosol - empregar uma tecnologia altamente especializada apta a garantir o retorno do crédito - retardou a abertura de linhas de financiamento de maior risco ou com instrumentos específicos, entre elas o Crédito Associativo, reservado a cooperativas e grupos de produção. O tímido apoio a empreendimentos associativos todavia não altera características de fundo desse modelo: a mobilização conjunta dos clientes e a criação de parcerias duráveis, haja ou não motivações extra-econômicas, apenas podem provir da confluência de interesses individuais, conforme sejam postos em reciprocidade. $\mathrm{O}$ solidarismo surge como possível decorrência da autodeterminação de sujeitos movidos por seus próprios interesses, não como requisito prévio desses ou uma dimensão imanente aos mesmos. Que a demanda provenha de indivíduos organizados, integrados ao circuito dos movimentos, é irrelevante. A premissa de que o caráter público de um serviço se cumpre à medida que é capaz de se universalizar conduziu a Portosol a adotar à risca o princípio de não pretender modificar indivíduos e grupos para lhes dar acesso aos benefícios. Respeitar a autodeterminação dos clientes, promovê-los como cidadãos, consiste, nesse caso, em responder a toda necessidade pertinente à missão institucional da agência, abstraindo-se todos os demais qualificativos dos sujeitos, inclusive o seu grau de adesão ao exercício contínuo de práticas solidárias. 
A estrutura da Portosol tem revelado capacidade ociosa, sendo visível a apatia dos aparatos de Estado que poderiam canalizar a ampla demanda social não atendida. O mesmo vale para as organizações sociais com atuação junto aos setores populares, as mesmas que levaram ao poder a frente política então à testa do governo e que representavam a sua base movimentalista de sustentação. Ora, uma ação incisiva, articulando as políticas de fomento da Instituição aos grupos populares da economia solidária, estimulados e acompanhados pelas demais organizações, certamente traria resultados relevantes e maior reconhecimento ao trabalho de umas e outras. Em boa medida, isso depende da capacidade de unir esforços e de aparar as diferenças de enfoque entre as modalidades de apoio aos empreendimentos. Isoladamente, as chances de cada programa e cada segmento da economia popular solidária são diminutas. Colocá-las em confluência requer, todavia, admitir que a maturação das experiências não conduz naturalmente à supressão dos seus aspectos singulares, em nome de uma visão e de uma política única.

\section{Segunda exigência: constituir um espaço público não-estatal}

A bem da verdade, no cenário atual há sinais positivos de compreensão desses problemas. A Associação Brasileira de Operadores e Gestores de Programas e Instituições de Microcrédito - ABCRED possui entre os seus filiados o CEAPE e a Portosol, entre outras iniciativas públicas, privadas ou estatais, o que favorece trocas constantes de experiências, comparativos entre modelos e formulações conjuntas. A modelagem das políticas municipais em São Paulo tem como premissa a agregação de competências e de possibilidades de intervenção dos aparelhos de Estado e das organizações civis. No correr de 2003, o amplo processo de mobilização nacional, com vistas à criação do Fórum Brasileiro de Economia Solidária, adotou por princípio reconhecer e valorizar a diversidade de iniciativas populares, organizações e atores que se perfilam no campo da economia solidária, ou que dele buscam aproximar-se. Não são diferentes os pressupostos anunciados quanto à condução política da Secretaria Nacional de Economia Solidária. Todavia, atores e estruturas desse porte, ao entrarem em cena, não apenas introduzem variáveis decisivas para o possível avanço da economia solidária, eles nos introduzem em uma nova totalidade, que vem a reposicionar os diversos atores e a incidir sobre novas relações, dialeticamente: superam-se determinados pontos da agenda, ao mes- 
mo tempo que afloram novos problemas já latentes ou doravante alimentados pela mudança de contexto, tornando inevitável o desenvolvimento de novas contradições.

No Rio Grande do Sul, os fatos são instrutivos: não obstante as condições políticas objetivamente propícias dos últimos anos, o estabelecimento de mecanismos sólidos para uma ampla ação de fomento deparou-se com diferenças de compreensão existentes há mais tempo, a começar pelos desencontros conceituais e de método que já assinalamos, cuja percepção mútua, em sendo duplamente enviesada, alimentou resistências de natureza política e ideológica. As organizações sociais reprovam a adesão acrítica à lógica econômica dominante do CEAPE e congêneres, o que terminaria convertendo seus beneficiários em reprodutores subalternos do sistema. Na mão oposta, não houve interesse visível em desencadear ações segundo as prescrições das organizações da economia solidária, pois isso obrigaria a introdução de mediações políticas que circunscrevem o raio de ação à parcela organizada e politizada dos trabalhadores ${ }^{18}$. Por sua vez, as coalizões de governo lideradas pelo PT faltaram com políticas efetivamente orgânicas, deixando suas ações vulneráveis, na prática, à disputa entre visões e interesses alojados no aparelho de Estado.

Para além das querelas, estiveram em jogo divergências e contendas quanto ao papel do Estado e ao caráter que deve possuir a esfera pública ${ }^{19}$. No caso em tela, o problema de fundo está em evitar que a ânsia de universalizar identidades coletivas particulares, quer de governos ou de organizações civis, conduza seus portadores a reduzir o âmbito universalista da esfera pública àqueles seus valores e critérios internos subjetivos, excluindo outros indivíduos e outros campos identitários (Doimo, 1995:182). Avançar nessa direção conduz ao equacionamento de algumas questões.

A primeira diz respeito ao lugar onde se devem concentrar os agentes e as forças dinâmicas da economia solidária. Para alguns, cabe ao Estado cumprir esse papel, chamando a si as organizações alinhadas com a sua visão estratégica e o seu programa de ação. Essa linha de conduta, majoritária no governo petista do Rio Grande do Sul, absorveu as demandas sociais da economia solidária no interior das políticas de Estado, operando de modo a preservar o controle das ações. Guardadas as proporções, a mesma lógica é verificável no comportamento de várias organizações: embora se disponham a reagir às intro- 
missões e à postura autocrática do Estado, não raro colocam a si próprias como expressão e representação legítima e bastante do interesse público, entendendo por isso o atendimento aos segmentos sociais que logram incorporar em seus programas de ação; um raciocínio auto-referenciado e circular, que deriva facilmente para uma lógica estreita de disputa por frações dos recursos públicos e quinhões do poder político ${ }^{20}$.

Quando o espaço público se reduz a mero prolongamento de grupos organizados ou de setores dotados de poder, vê-se condenado a reproduzir mecanismos de distribuição seletiva dos bens públicos, desprovidos de regras universalistas e de princípios efetivamente democráticos, para não mencionar o nosso histórico déficit democrático, agravado com as posturas instrumentais sobejamente correntes na direita e na esquerda. Nessa lógica, inexistindo critérios regulatórios, como frisa Doimo, "o que conta é isso: quem se organiza mais e faz mais pressão é quem leva as fatias do fundo público" (idem:60). Se a esfera político-institucional é legitimamente o terreno de disputa de visões e interesses, agem naquele sentido as visões que, amparando-se no aparelho de Estado, fazem da esfera pública uma simples extensão de grupos de interesse.

Como segundo argumento, no Brasil é necessário recuperar as funções específicas e as prerrogativas da esfera político-institucional, de certo modo revertendo a excessiva politização da vida pública. $\mathrm{Ou}$ seja, o Estado é naturalmente uma arena de contendas, um alvo de disputa política, cuja resolução momentânea toma corpo em programas de governo. Aos interesses políticos alçados ao comando do aparelho estatal, pelos mecanismos democráticos de representação, compete agir legitimamente sobre todos os setores. Contudo, se exercem, além disso, a condução dos processos, valendo-se ademais da inigualável capacidade provedora do Estado, terminam por submeter as políticas públicas, bem como as respectivas organizações da sociedade civil, à ciranda das políticas de governo, conhecidas por sua instabilidade e descontinuidade.

A centralidade dada ao Estado parece igualmente decorrer da aversão existente ao mercado, visto em termos dualistas como sendo a outra única alternativa. Naturalmente, essa visão já não se sustenta diante dos fatos e da sua atual compreensão teórica. Para referir apenas às teses da nova sociologia econômica, Laville (1997), retomando Karl 
Polanyi, apresenta a economia moderna articulada em três campos originários: a economia mercantil, a economia não mercantil e a economia não monetária, as quais correspondem, respectivamente, os princípios do mercado, da redistribuição e da reciprocidade. O terceiro elemento compreende iniciativas e processos de vida associativa em que predominam fatores humanos e relações de troca a longo termo, orientadas por uma racionalidade não-estatal e não mercantil. Ele constitui uma fonte de sinergia das forças vivas da sociedade, cujo dinamismo redefine o papel dos demais pólos e abre novos rumos para a sociedade, como sinaliza a revitalização da economia social em países do Norte.

Do mesmo modo, pode-se situar o centro de gravidade da economia solidária nesse espaço intermediário, híbrido e relacional, dotando-o de mecanismos capazes de atrair uma pluralidade de atores, de diferentes matizes, de cuja interação resultem compromissos de longo prazo, com diretrizes e programas de desenvolvimento. Trata-se, em suma, de postular uma esfera pública não-estatal, no mesmo sentido retomado por Jean-Louis Laville, Hanna Arendt e Jürgen Habermas, a propósito do lugar e significado original do espaço público político: "um espaço de interações engendrado pelos cidadãos, quando se engajam numa ação de intercompreensão [...] [o qual] não postula ser homogêneo mas, ao contrário, admite as diferenças e o debate" (Laville, 2002:1, nota do tradutor). Os traços da economia solidária, como já indicamos, especialmente sua vocação plural e sua conformação policêntrica, advogam decisivamente em favor desse entendimento.

Essa compreensão ajuda ainda a conceber cada segmento da economia solidária, com seus respectivos programas de fomento, como formas de atender a situações específicas. Caminhar para ações mais abrangentes não significa anular essas diferenças, mas introduzir vias de conexão e novos serviços, cujas modelagem e experimentação suportem uma mudança de escala progressiva. Tampouco convém perder de vista que as expectativas dos trabalhadores exorbitam legitimamente a visão de mundo proposta por teorias orientadas desde uma utopia, como a economia solidária. Isso implica abertura para outras modalidades de atuação, com agregação de experiências e de esforços, validando-as pelo aporte que trazem à vida real dos setores populares, não por seu presumido grau de alinhamento ideológico. 


\section{Terceira exigência: cruzar fronteiras}

Essa perspectiva demanda atravessar fronteiras, reais e imaginárias, para visualizar a economia solidária além das experiências particulares que a tornaram uma realidade concreta e dos recortes político-ideológicos das organizações que lhe dão significado. No fundo, trata-se de coibir uma tendência espontânea de projeção, pela qual a realidade social, em seu todo, adquire as cores e o sentido que possui em um campo singular. Ora, o principal conjunto de experiências e de fomentos ao solidarismo econômico popular, gerado nos últimos dez anos, ambienta-se nas redes movimentalistas. Tais redes, como vimos, não obstante seu apelo universalizante, estão circunscritas a um determinado círculo de representações e relações. Os requisitos para o atendimento das demandas que nelas se manifestam, bem como a eficácia dos seus processos decisórios, não podem ser transladados, sem mais, ao tratamento público da cidadania. Supor que a capacidade de mobilização e de pressão sejam atributos naturais do tecido popular, bastando neutralizar os fatores impeditivos a que este faça valer sua coesão interna, apenas levaria a excluir os já excluídos. Como então viabilizar políticas públicas e programas de massa sem romper com processos e critérios seletivos que, embora úteis e justificáveis no âmbito de ações de apoio modelares e focalizadas, restringem o seu alcance social? Confluindo mais uma vez com Doimo (1995:60), a única forma de contornar a corrida entre diversos grupos segmentados, concomitantemente mobilizados, é instituir políticas regulatórias, vinculadas a propriedades da população a atingir e à natureza universal da ação pública, de modo a cortar transversalmente os grupos de interesse e chegar a todos os beneficiários potenciais.

A economia solidária favorece ainda que se derrubem fronteiras artificiais, criadas pelo pensamento, entre as esferas econômica, social e política da vida coletiva. Contra o economicismo e toda visão unilateral, a racionalidade de que estão dotados os seus empreendimentos envolve essas dimensões simultaneamente e implica uma abordagem sintonizada com suas múltiplas exigências e influências recíprocas. Condição similar à que se observa em outros contextos, como a Europa, onde

"Essas iniciativas locais possuem mais que um papel econômico. Ativando elos próximos de solidariedade, essas iniciativas exercem também um papel social; atribuindo aos membros da sociedade civil a ex- 
pressão e ação vinculadas à satisfação de necessidades sociais, elas se revelam igualmente políticas" (Caillé e Laville, 1996:86).

Os empreendimentos solidários enraízam-se na comunidade, promovem a participação, dinamizam redes de interação e fomentam a democracia política ${ }^{21}$. Abrem vias, portanto, para que se cruze o espaço territorial e social, do micro ao macro, do local ao mundial. À base desse alargamento de horizontes está o fato primordial de que, contrariamente à volubilidade e volatilidade das empresas de capital, tais empreendimentos estão colados ao trabalho, a pessoas que vivem, residem e se relacionam de acordo com identidades e projetos vinculados a um território e a um sentimento de pertença. As práticas de autogestão desses empreendimentos os configuram como um "espaço público autônomo" (Laville, 2002:3) ou como "espaços públicos de proximidade [...] permitindo aos que neles participam, tomar a palavra, debater, decidir e levar à obra projetos econômicos em resposta aos problemas sociais que encontram" (Caillé e Laville, 1996:86).

Essa inserção local da economia solidária a induz a se apoiar no que está à mão - trabalho, saberes, energias morais, recursos políticos e institucionais -, explorando e revitalizando matrizes produtivas dotadas de racionalidade social. Contribui para "dinamizar o enorme potencial de recursos humanos e materiais que jaz em repouso nas 'esferas' não-mercantis e mercantis da sociedade" (Franco, 1996:12). Nem toda atividade econômica, interessando ao trabalho, é atraente para o capital, podendo ter sido sufocada ou abandonada por este. Contrariando uma percepção monolítica do espaço econômico, as empresas solidárias tendem a recuperar vocações regionais, a ocupar nichos menos cobiçados pela grande concorrência, a estabelecer relações de troca favorecidas pela confiança conquistada junto a seus clientes. Tais relações de proximidade são em verdade um patrimônio da economia popular, ou do andar de baixo da civilização, como diria F. Braudel.

O estudo de Putnam, ao elucidar as razões do desenvolvimento desigual da Itália moderna, põe em evidência o papel decisivo das associações e demais estruturas sociais coletivas, na medida em que estas incutem em seus membros hábitos de cooperação, solidariedade e espírito público, produzindo uma "competência cívica subjetiva", e intensificam a articulação e a agregação de interesses (Putnam, 1996:103-104). A presença dessas organizações constitui um pilar fun- 
damental do capital social, isto é, de práticas sociais de confiança, normas e sistemas que contribuem para aumentar a eficiência da sociedade, facilitando as ações coordenadas, materializando soluções coletivas e coibindo o oportunismo individualista. Como diz Putnam, o capital social é um bem público, indivisível, pois atributo da estrutura social, na qual se generalizam relações de reciprocidade.

Embora a economia solidária necessite se prover de mecanismos próprios de alimentação e de algum grau de autonomia, é implausível imaginar que possa consolidar-se e sobreviver como um quisto isolado, no interior de um sistema econômico hegemônico e hostil. A partir do âmbito local, ela evidencia confluir para outro padrão geral de desenvolvimento humano e sustentável. Este requer a cooperação de atores socioeconômicos, em âmbitos territoriais limitados, capazes de sustentar processos endógenos, simultaneamente conectados com processos globais, posto que as metas almejadas por esse novo paradigma, de direitos humanos e qualidade de vida, não são de domínio exclusivamente local (Coraggio, 2001b). Tal conexão pode viabilizar ampliação de escala e incidir sobre o plano institucional para que se abram novas possibilidades.

Para o Rio Grande do Sul, o espaço de integração macrorregional a ser considerado, além do Brasil, são os países vizinhos, cujas relações vêm sendo pautadas pelos acordos do Mercosul. Até o momento, as iniciativas nesse âmbito primaram pela instabilidade, por causa das crises e sobressaltos por que têm passado os países signatários, e pela ênfase nos aspectos de comércio, no qual interesses conflitivos têm gerado constantes intransigências. Além disso, é francamente débil a atuação de representações da sociedade civil. Não obstante esses limites $^{22}$, a deliberação de criar um espaço político e econômico determinado por acordos multilaterais, e não simplesmente pelas quedas-de-braço e pelo oportunismo característico da livre concorrência, representa um passo importante. Os princípios de integração e de normatização, mediante acordos sucessivos, estão postos - fato de vital importância em um mundo cada vez mais desregulamentado (Cruz e Vázquez, 1998). Cabe aos agentes da economia solidária incrementar os contatos e os incipientes intercâmbios na região, como meio de pôr em prática laços de reciprocidade e gerar experiências que embasem, seja a atuação de seus porta-vozes nas instâncias do Mercosul $^{23}$, sejam as propostas de novas regras econômicas, concernentes ao trabalho, aos direitos sociais e às instituições políticas. De 
pouco vale abominar as questões do mercado se, em um sistema de troca entre produtores e consumidores solidários, mesmo buscando otimizar os interesses recíprocos, hão de persistir interesses contrapostos, e não exclusivamente complementares, a exigir negociações e $\operatorname{acordos}^{24}$.

\section{Quarta exigência: promover o protagonismo cívico}

Uma das estratégias mais poderosas utilizadas pelos grupos dominantes, para preservar sua posição, realiza-se pela cooptação dos intelectuais que a dialética social gera continuamente, seja caso a casode forma molecular, na expressão de Antonio Gramsci -, seja pela absorção ideológica dos novos estamentos intelectuais. Seu efeito mais nefasto é a separação entre os intelectuais e as classes subalternas, fato mais provável em três circunstâncias: a) quando é grande o poder de sedução exercido pelos intelectuais das classes dominantes sobre os demais, que migram de posição imperceptivelmente; b) quando, por uma virada histórica, os intelectuais contestadores se vêem guindados a ocupar espaços institucionais e políticos até então cativos dos grupos dominantes, que a eles impingiram uma cultura política e regras de funcionamento a serviço da sua dominação; c) quando os intelectuais contestadores da ordem, eventualmente nas circunstâncias anteriores, sentindo abrirem-se novos espaços à sua frente, assumem o protagonismo do processo histórico, em nome dos grupos subalternos que em tese representam, mas também em seu lugar, a pretexto da urgência dos fatos e da falta de organicidade de tais grupos.

É desnecessário argumentar quanto aos riscos dessa natureza, contidos na totalidade histórica que se apresenta em nosso país. Quando os intelectuais substituem o protagonismo popular, em verdade separam-se das classes subalternas, pois o problema destas é justamente a sua exclusão como sujeitos, sua falta de ação histórica, cuja promessa mais uma vez fica adiada. Além do mais, ocorre que os intelectuais em questão tenderão inevitavelmente a colocar em primeiro plano os seus problemas e interesses, entre eles os embates de natureza puramente ideológica e as disputas corporativas por espaço e sobrevivência. Como diria Gramsci, a contenda desloca-se da infra-estrutura, dos problemas reais de estrangulamento das novas práticas dos trabalhadores, para a superestrutura, na qual fica seccionada da práxis social. 
Por razões históricas compreensíveis, os rumos da economia solidária dependem em grande medida das organizações sociais e dos agentes mediadores. Destes, depende também o aprofundamento dessa correlação de forças ou a sua reversão em favor do ator popular. A segunda opção implica destituir-se continuamente do poder que as circunstâncias momentâneas venham a conferir supletivamente aos intelectuais, bem como idealizar estruturas de poder sensíveis e permeáveis à dinâmica dos sujeitos primeiros da economia solidária. Significa ainda, mantendo a linguagem gramsciana, preservar a sociedade civil como terreno primordial de luta pela introdução de novos valores e novas práticas - de disputa pela hegemonia - cuja ausência, precisamente, converte o Estado em pólo decisivo e deixa a seu arbítrio dotar-se de parâmetros ético-políticos.

Ponderando os fatos por outro ângulo, caberia reconhecer que as funções de direção e operação dos aparatos institucionais são tipicamente intelectuais. A esse respeito, Putnam demonstra de maneira irretorquível que o desempenho institucional decorre em grande proporção da existência de uma comunidade cívica, assente em mecanismos de participação e em práticas de solidariedade. A ação institucional não consegue suprir a ausência do civismo, mas deve promovê-lo se desejar evitar ou interromper ciclos viciosos estagnantes, nos quais a vida social não se referencia em estruturas próprias, mas sim no Estado e em seus aparatos, politizando-se verticalmente na mão oposta ao civismo. Trata-se então de legitimar as mais diversas formas de solidariedade, de estimular as atitudes de confiança, cujo exercício tem a grande vantagem de ser cumulativo e se reforçar mutuamente. A passagem a círculos virtuosos redunda "em equilíbrios sociais com elevados níveis de cooperação, confiança, reciprocidade, civismo e bem-estar coletivo" (Putnam, 1996:186).

\section{CONSIDERAÇÕES FINAIS}

Em seus horizontes atuais, a economia solidária se vê impulsionada por sua capacidade de responder a situações dramáticas de luta pela sobrevivência, por direitos e por dignidade, mas sua presença a longo prazo dependerá de sua eficácia em assegurar a reprodução de amplos setores sociais e propiciar-lhes uma vida melhor. Por estar estruturalmente orientada de modo antagônico à economia do capital, apenas poderá fazê-lo gerando conflitos e tensões, cobrando continuamente ao sistema dominante que resolva os problemas de inte- 
gração de todos os membros da sociedade. Assim, ao mesmo tempo que estimula maior funcionalidade do sistema, ela fortalece ou suscita a constituição de novos atores coletivos, portadores de uma crítica teórica, política e filosófica à ordem social atual, e de um projeto de substituição global. Sejam quais forem os desafios a superar no futuro próximo, diversos caminhos terá a trilhar. Provavelmente, no lugar de um processo de ruptura súbita e plena reconstrução, esteja mais de acordo com a história conceber sucessivas mutações, nas práticas econômicas e nos mecanismos de representação, em direção a um sistema híbrido, de economia plural e de alargamento democrático, cujo ponto de equilíbrio será função da capacidade de alianças e da força de embate dos atores oponentes.

(Recebido para publicação em setembro de 2003)

(Versão definitiva em junho de 2004)

\section{NOTAS}

1. Um dos esforços consideráveis em apreender as práticas e as teses desta outra mundialização, mediante ampla pesquisa internacional, está sendo liderado por Boaventura de Sousa Santos, resultando na obra Reinventar a Emancipação Social (vários volumes, ver Santos, 2002). O livro Sentidos e Experiências da Economia Solidária no Brasil (Gaiger, 2004) constitui o primeiro estudo de base nacional, com pesquisas em diversas regiões do país.

2. Que o caso do Rio Grande do Sul seja emblemático de alguns problemas, obviamente não autoriza generalizá-los sem mais ao país. As políticas públicas de economia solidária em cidades como São Paulo e Belém, por exemplo, evidenciam outras determinações em suas concepções e métodos.

3. Também designada, ao Norte, como nova economia social, ou economia social e solidária, entre outras denominações (cf. Laville, 1994; Defourny et alii, 1999).

4. Para um tratamento detalhado dessas questões, ver Gaiger (2001b).

5. O termo segmento refere-se ao conjunto das organizações populares vinculadas a uma determinada agência, órgão de fomento ou programa. Dado o peso dessas externalidades, tais vínculos normalmente conferem feições comuns àquelas organizações e com razoável intensidade afetam o seu desenvolvimento.

6. Para uma visão mais abrangente e detalhada da economia solidária no Rio Grande do Sul, ver Sarria (2002) e Gaiger (2004). 
7. Parte das atuais questões polêmicas sobre o MST encontra-se em Santos (2002, caps. 4 a 6 ).

8. Mesmo o cooperativismo, não obstante sua tradição política própria, busca nesse momento se conectar com esses caminhos. O segmento de cooperativas de trabalho, por exemplo, tem pleiteado explicitamente seu reconhecimento como parte da economia solidária.

9. Uma peculiaridade da Portosol reside na sua origem: idealizada por obra da segunda gestão petista do poder municipal de Porto Alegre, recebeu uma personalidade jurídica e uma estrutura de gestão independentes da esfera estatal. O fato, à época, refletiu uma política social incomum no país: configurar uma esfera pública nãoestatal, com função econômica estratégica para o desenvolvimento local, estreitamente vinculada às prioridades do poder público. Sendo uma instituição autônoma, sem recursos a fundo perdido, com a missão de atestar a viabilidade dos investimentos em microempreendimentos, o apoio aos mesmos foi concebido sob a premissa de resguardar a auto-suficiência financeira da Portosol, com repasse ao tomador dos seus custos operacionais. O atrativo do crédito depende, então, da eficiência operacional da instituição.

10. A discussão sobre as vantagens produtivas da participação dos trabalhadores naturalmente não é nova (Defourny, 1988) e tampouco restrita aos empreendimentos de autogestão (Coutrot, 1999). Uma análise de dados empíricos, de empreendimentos solidários no Rio Grande do Sul, encontra-se em Gaiger (2001b).

11. Para uma avaliação correta, o conceito de eficiência deixaria de estar restrito à relação custo/benefício, para compreender o conjunto de benefícios, diretos e indiretos, gerados em prol da qualidade de vida dos trabalhadores e do entorno social em que vivem (Gaiger, 2003a).

12. Programas semelhantes foram implantados em outros municípios, perfazendo meia centena de empreendimentos e havendo, ademais, subsidiado uma das linhas de trabalho do governo Olívio Dutra.

13. Projetos de estímulo à qualificação e à comercialização dos produtos solidários, ou possuem um efeito momentâneo e economicamente restrito, como as Feiras de Economia Solidária, ou estão por evidenciar sua viabilidade, como a Etiqueta Popular e a Central de Comercialização, ou representam espaços de discussão entre os agentes, indispensáveis mas sem garantia de resultados concretos, como o Fórum Estadual de Economia Solidária.

14. Concretizando a intenção de inverter as prioridades, anunciada pelo governo petista, os programas para a economia solidária somaram-se a outros (Cooperar-RS, Rio Grande Ecológico, Extensão Empresarial etc.) dirigidos às cooperativas, aos pequenos produtores rurais e aos pequenos e médios empresários.

15. Ao final do mandato (junho de 2002), uma derradeira e frustrada tentativa de reverter esse quadro traduziu-se na assinatura de convênios de cooperação com ONGs e universidades do estado, para fins de assessoria e sustentação a 350 empreendimentos. Além de problemas sérios de concepção e do clima já instalado de disputa por recursos, em uma conjuntura pré-eleitoral, o programa feneceu diante do descumprimento de grande parte dos repasses por parte do governo. 
16. O fato tem despertado o interesse do sistema bancário tradicional, o que pode redundar em um aumento da oferta de microcrédito, ao mesmo tempo que introduz novas variáveis no problema, para não falar do programa de acesso popular ao sistema bancário e ao crédito lançado pelo governo Lula em meados de 2003.

17. A retaguarda do CEAPE é formada sobretudo por entidades empresariais e bancos estatais, executores das políticas do governo federal.

18. Por trás dessas contraposições discursivas, utilizam-se com freqüência metodologias e instrumentos de trabalho muito semelhantes, seja no diagnóstico dos empreendimentos seja na pedagogia de educação.

19. Debate no qual se encontra bem avalizada a tese que distingue o espaço público do Estado e reivindica que este se torne de fato público, por meio de maior controle social sobre a ação estatal, enquanto se fortalecem os direitos e processos de organização cívica (Bresser Pereira e Grau, 1999).

20. Glosando Banfield (apud Putnam, 1996), as versões mais extremas dessa conduta se assemelham ao que poderíamos chamar de "sectarismo amoral", em que cada facção procura maximizar suas vantagens materiais e políticas imediatas, na suposição de que as demais se comportam da mesma forma; o domínio público fica reduzido a um campo de batalha, em que se afirmam unicamente interesses particulares em detrimento dos princípios republicanos e de práticas cívicas autênticas.

21. Dizendo de outro modo, eles geram postos de trabalho, incrementam o Produto Interno Bruto - PIB dos municípios, conquistam escolas e postos de saúde, atraem serviços técnicos, criam associações comunitárias etc.

22. Para um balanço dos avanços e déficits do Mercosul, ver Gómez (2000).

23. Especialmente pelo Fórum Consultivo Econômico e Social, no qual, por exemplo, há representação do setor cooperativista de alguns países.

24. Para ficar em um segundo exemplo, é sabido que a transnacionalização das relações de trabalho, propiciando práticas de dumping social pelas empresas, acarreta desequilíbrios profundos, sendo urgente instaurar dispositivos de proteção ao trabalhador com abrangência internacional (Lima, 2002). 


\section{REFERÊNCIAS BIBLIOGRÁFICAS}

ANTUNES, Ricardo. (1999), Os Sentidos do Trabalho. São Paulo, Boitempo Editorial.

ARRUDA, Marcos. (1998), O "Feminino Criador": Socioeconomia Solidária e Educação. Rio de Janeiro, Instituto de Políticas Alternativas para o Cone Sul.

BRESSER PEREIRA, Luiz e GRAU, Nuria (orgs.). (1999), O Público Não-Estatal na Reforma do Estado. Rio de Janeiro, Fundação Getulio Vargas Editora.

CAILLÉ, Alain e LAVILLE, Jean-Louis. (1996), “Pour ne pas Entrer à Reculons dans le XXIe Siècle". Extrait du Débat, no 89, pp. 80-89.

CAMACHO, Ildefonso. (1996), “Economía Alternativa en el Sistema Capitalista". Revista de Fomento Social, no 51, pp. 319-340.

CÁRITAS BRASILEIRA. (2003), Vinte Anos de Economia Popular Solidária. Brasília, Cáritas.

CORAGGIO, José Luis. (1997), “Alternativas para o Desenvolvimento Humano em um Mundo Globalizado". Revista Proposta, no 72, pp. 30-38.

. (2001a), Problematizando la Economía Solidaria y la Globalización Alternativa. Trabalho apresentado no II Encuentro Internacional sobre la Globalización de la Solidaridad. Québec, novembro.

. (2001b), "La Relevancia del Desarrollo Regional en un Mundo Globalizado". Revista Ciências Sociais Unisinos, vol. 37, no159, pp. 235-258.

COUTROT, Thomas. (1999), Critique de l'Organisation du Travail. Paris, La Découverte.

CRUZ, Anabel e VÁZQUEZ, Graciela. (1998), Puede el Mercosur Contribuir a Combatir la Exclusión Social? Trabalho apresentado no 1으 Congresso Latino-Americano da International Society for Third-Sector Research. Rio de Janeiro.

CRUZ, Antônio. (2002), Uma Contribuição Crítica às Políticas Públicas de Apoio à Economia Solidária. Campinas, SP, UNICAMP.

DEFOURNY, Jacques. (1988), “Coopératives de Production et Entreprises Autogérées: Une Synthèse du Débat sur les Effets Economiques de la Participation". Mondes en Développement, vol. 16, no 61, pp. 139-153.

_ DEVELTERE, Patrick e FONTENEAU, Bénédicte (eds.). (1999), L'Économie Sociale au Nord et au Sud. Bruxelas, De Boeck.

DOIMO, Ana. (1995), A Vez e a Voz do Popular. São Paulo, AnPocs/Relume-Dumará.

DUBET, François. (1994), Sociologie de l'Expérience. Paris, Seuil.

FRANCO, Augusto. (1996), “Uma Nova Perspectiva Estratégica Pós-Liberal para Enfrentar a Questão Social no Brasil". Revista Proposta, n을, pp. 10-17.

GAIGER, Luiz. (1999), "Significado e Tendências da Economia Solidária”, in Central Única dos Trabalhadores - CUT (org.), Sindicalismo e Economia Solidária. São Paulo, CUT.

. (2001a), "As Organizações do Terceiro Setor e a Economia Popular Solidária". Revista Ciências Sociais Unisinos, vol. 37, n -159, pp. 103-151. 


\section{Luiz Inácio Gaiger}

. (2001b), "Virtudes do Trabalho nos Empreendimentos Econômicos Solidários". Revista Latinoamericana de Estudios del Trabajo, vol. 7, no 13, pp. 191-211.

. (2003a), "Eficiência Sistêmica", in A. Cattani (org.), A Outra Economia. Porto Alegre, Veraz, pp. 125-129.

. (2003b), “L'Economie Solidaire au Brésil”. Recherches - Revue du M.A.U.S.S., n-o21, pp. $80-96$.

. (2004), Sentidos e Experiências da Economia Solidária no Brasil. Porto Alegre, Ed. UFRGS, Coleção Sociedade e Solidariedade.

GÓMEZ, José María. (2000), Política e Democracia em Tempos de Globalização. Petrópolis, RJ, Vozes.

LAVILLE, Jean-Louis (org.). (1994), L'Economie Solidaire: Une Perspective Internationale. Paris, Desclée de Brouwer.

. (1997), "Le Renouveau de la Sociologie Economique". Cahiers Internationaux de Sociologie, vol. CIII, pp. 229-235.

. (2002), Démocratie et Economie: Eléments pour une Approche Sociologique. Paris. Manuscrito.

LIMA, Otávio. (2002), As Multinacionais e as Relações Trabalhistas no Mercosul. Disponível na internet em <http://sites.uol.com. br/globalization>.

NOVE, Alec. (1989), A Economia do Socialismo Possível. São Paulo, Ática.

PEIXOTO, José. (2000), “Autogestão: Um Modelo Alternativo de Reestruturação da Produção", in O. Ponte Jr. (org.), Mudanças no Mundo do Trabalho: Cooperativismo e Autogestão. Fortaleza, Expressão.

PUTNAM, Robert. (1996), Comunidade e Democracia: A Experiência da Itália Moderna. Rio de Janeiro, Fundação Getulio Vargas Editora.

SANTOS, Boaventura de Sousa (org.). (2002), Produzir para Viver: Os Caminhos da Produção Não Capitalista. Rio de Janeiro, Civilização Brasileira.

e RODRÍGUEZ, César. (2002), "Para Ampliar o Cânone da Produção", in B. de S. Santos (org.), Produzir para Viver: Os Caminhos da Produção Não Capitalista. Rio de Janeiro, Civilização Brasileira, pp. 23-77.

SARRIA, Ana. (2002), Solidariedade, Autogestão e Cidadania: Mapeando a Economia Solidária no Rio Grande do Sul. São Leopoldo. Manuscrito

SEDAI - Secretaria do Desenvolvimento e Assuntos Internacionais do Governo do Estado do Rio Grande do Sul. (2001), Programa de Economia Popular Solidária. Porto Alegre, SEDAI.

SENNETT, Richard. (1999), A Corrosão do Caráter: Conseqüências Pessoais do Trabalho no Novo Capitalismo. Rio de Janeiro, Record.

SINGER, Paul e SOUZA, André (orgs.). (2000), A Economia Solidária no Brasil: A Autogestão como Resposta ao Desemprego. São Paulo, Contexto. 


\section{ABSTRACT}

The Solidarity Economy and the Alternative Globalization Proposal

The striking events of the World Social Forums, succeeded by the entry of new actors into the Brazilian political scenario launched in 2003, involved a set of both promising and unknown new possibilities for the solidarity economy. The understanding of such moments, signaling both future advances and questions, requires examining recent steps in order to unveil the meaning of the new pathways and the demands they raise, given the new choices that need to be made. This article discusses the formulations of militant praxis in the solidarity economy and analyzes some of the problems permeating its history in recent years, based primarily on empirical studies on its evolution in the State of Rio Grande do Sul in relation to actual experiences and mediating organizations. The paper identifies some of the necessary changes and innovations in the conceptualization and implementation of the solidarity economy, in the sense of expanding its frontiers and legitimizing and agglutinating its various watersheds and expressions in order to establish it as an effective pillar for an alternative development and globalization process.

Key words: work; popular economy; self-management; public space

\section{RÉSUMÉ}

L'Économie Solidaire et le Projet d'un Alter-mondialisme

Les grands événements des Forums Sociaux Mondiaux, qui ont été suivis de l'entrée en scène de nouveaux acteurs dans la conjoncture politique brésilienne inaugurée en 2003, renferment probablement un ensemble de nouvelles possibilités pour l'économie solidaire, à la fois prometteuses et inconnues. Pour comprendre ces moments, marques de progrès pour l'avenir mais aussi d'interrogations, il faut examiner le trajet déjà parcouru, afin de comprendre à partir des enseignementsr le sens des chemins qui s'ouvrent ainsi que leurs exigences et se préparer ainsi à de nouveaux choix. Dans ce travail, on discute les principes de la pratique militante de l'économie solidaire de même que quelques problèmes qui ont marqué son histoire ces dernières années, en prenant appui surtout sur des études empiriques à propos de son évolution à Rio Grande do Sul, quant aux expériences concrètes et aux organisations de médiation. On y identifie quelques-uns des changements et innovations nécessaires, dans la conception et la conduite de 
l'économie solidaire, en vue d'élargir ses frontières, en légitimant et assemblant ses divers versants et expressions, pour en faire un vrai pilier d'un autre processus de développement et de mondialisation.

Mots-clé: travail; économie populaire; autogestion; espace public 